\title{
TRIGGER FACTORS IN MIGRAINE PATIENTS
}

\author{
Patrícia Timy Fukui', Tessa Rachel Tranquillini Gonçalves', Cintia Giunchetti Strabelli', \\ Natalia Maria Fernandes Lucchino', Fernanda Cunha Matos', Juliana Pinto Moreira dos Santos', \\ Eliova Zukerman ${ }^{2}$, Vera Zukerman-Guendler ${ }^{2}$, Juliane Prieto Mercante ${ }^{2,4}$, \\ Marcelo Rodrigues Masruha ${ }^{2,3}$, Domingos Sávio Vieira ${ }^{2,3}$, Mario Fernando Prieto Peres ${ }^{1,2,3}$
}

\begin{abstract}
Background: Migraine is a chronic neurological disease with several trigger factors, including dietary, hormonal and environmental factors. Purpose: To analyse precipitating factors in a sample of migraine patients. Method: Two hundred consecutive migraine patients were interviewed about possible trigger factors for migraine attacks. Results: Most patients showed at least one dietary trigger, fasting was the most frequent one, followed by alcohol and chocolate. Hormonal factors appeared in $53 \%$, being the pre-menstrual period the most frequent trigger. Physical activities caused migraine in $13 \%$, sexual activities in $2.5 \%$ and $64 \%$ reported emotional stress a trigger factor. $81 \%$ related some sleep problem as a trigger factor. Regarding environmental factors, smells were reported by $36.5 \%$. Conclusion: Trigger factors are frequent in migraine patients, its avoidance may decrease headache frequency and also improve patients' quality of life.
\end{abstract}

KEY WORDS: migraine, trigger factors.

\section{Fatores desencadeantes de enxaqueca}

Resumo - Introdução: A enxaqueca é uma doença neurológica crônica que apresenta diversos desencadeantes como fatores alimentares, hormonais e ambientais. Objetivo: Analisar os fatores desencadeantes em uma amostra de pacientes com enxaqueca. Método: Duzentos pacientes com diagnóstico de enxaqueca foram questionados sobre fatores que pudessem desencadear suas crises. Resultados: 83,5\% apresentaram algum fator alimentar, jejum foi o fator mais freqüente, seguido de álcool e chocolate. Dos fatores hormonais, o período pré-menstrual foi o mais freqüente. Atividade física causou enxaquecas em $13 \%$, atividade sexual em $2,5 \%$, estresse em $64 \%$ e $81 \%$ relataram o sono como fator desencadeante. Em relação aos fatores ambientais, odores foram desencadeantes em $36,5 \%$. Conclusão: Os fatores desencadeantes são freqüentes em enxaqueca e a sua detecção deve ser pormenorizada para que se reduza a freqüência de crises e melhore a qualidade de vida do paciente.

PALAVRAS-CHAVE: enxaqueca, fatores desencadeantes.

Migraine is a chronic debilitating neurological condition with several trigger factors. It usually begins in childhood or adolescence and can remain with the patient for the whole life. It is more common in women than men, its prevalence is $12 \%$ of the general population, affecting $18 \%$ to $20 \%$ of women, occurring mainly during their productive and reproductive phases ( 20 to 50 years old). Therefore, migraine has a significant socioeconomic impact and in patients quality of life'. Migraine is a complex disorder with several pathopsysiological mechanisms involved, such as hypothalamic dysfunction shown by a chronobiologic dysregulation, and a possible hyperdopaminergic state $^{2}$. A variety of external and internal factors have been demonstrated to precipitate migraine attacks.
Trigger factors are important in migraine management since their avoidance may result in a better control of the disorder. Several studies are consistent with stress, lack of sleep, and fasting being the most common trigger factors ${ }^{3,4}$, but some other factors such as including alcohol intake, excessive caffeine consumption, and hormonal factors in women are also recognized. In spite of its importance, little is known about migraine trigger factors in our society.

The aim of this study was to make an analysis of the precipitating factors in a sample of Brazilian migraine patients.

\section{METHOD}

We studied 200 migraine patients diagnosed according to

\footnotetext{
'Liga de Cefaléia da Faculdade de Medicina do ABC, São Bernardo SP, Brazil; ${ }^{2}$ Instituto Israelita de Ensino e Pesquisa Albert Einstein, São Paulo SP, Brazil; ${ }^{3}$ Neurociências, Universidade Federal de São Paulo, São Paulo SP, Brazil; ${ }^{4}$ AMBAN, Instituto de Psiquiatria da FMUSP, São Paulo SP, Brazil.
}

Received 4 October 2007, received in final form 6 June 2008. Accepted 23 June 2008.

Dr. Mário F. Prieto Peres - Rua Joaquim Eugênio de Lima 881 / 708 - 01403-001 São Paulo SP - Brasil. E-mail: marioperes@yahoo.com 
the International Classification of Headache Disorders ${ }^{5}$. One hundred and sixty two women and thirty eight men were specifically asked about presence or absence of possible trigger factors for their migraine attacks.

A pre-determined list of trigger factors including: dietary (chocolate, sausage, salami, monosodium glutamate, cheese, milk, aspartame, alcohol, red wine, white wine, coffee, soft drink, citric fruits, icecream and nuts), fasting, hormonal factors (menstruation, pre menstrual period, after menstrual period, pregnancy, menopause, ovulation and hormonal replacement), sleep (oversleep, lack of sleep, changes in time of sleep, weekend), stress (at work, at home and family, crying, conflict, argument and aggressiveness), exertional activities (physical, sexual, coughing, sneezing, to lift weight, evacuation) and environmental (allergy, pollution, wind, rain, height, sun/clarity, cold weather, hot weather, changes in the weather, cigarette, air conditioning in the car, home or work, odors of perfumes, food, fat, cleanness product and gasoline).

The study was performed by medical students at the Liga de Cefaleia of $A B C$ Medical School under the supervision of the senior author (MFPP) .It was approved by the Etic Committed in Research of FMABC and registered under the number of 028/2007.
Table 1. Trigger factors in migraine patients according to gender.

\begin{tabular}{lcccc}
\hline & $\begin{array}{c}\text { Female } \\
\%\end{array}$ & $\begin{array}{c}\text { Male } \\
\%\end{array}$ & $\begin{array}{c}\text { Total } \\
\%\end{array}$ & $\begin{array}{c}\text { Factors } \\
\text { avarage }\end{array}$ \\
\hline Fasting & 65.43 & 55.26 & 63.50 & \\
Dietary & 64.81 & 60.53 & 64.00 & 4.70 \\
Hormonal & 53.70 & 0.00 & 43.50 & 0.95 \\
Sleep & 75.90 & 73.60 & 75.50 & 2.30 \\
Activities & 12.90 & 26.30 & 15.50 & 0.23 \\
Stress & 65.40 & 63.10 & 65.00 & 1.64 \\
Environmental & 74.00 & 44.70 & 68.50 & 3.18 \\
Minimum of 1 factor & 100 & 100 & & \\
Minimum of 2 factors & 96.30 & 92.10 & & \\
\hline
\end{tabular}

\section{RESULTS}

Two hundred patients were analyzed, 162 women (81\%) and 38 men (19\%). The mean age of female patients was $37.0 \pm 11.14$ and $40.7 \pm 14.20$ for male, the total average was 37.7. The most common group of trigger factors was dietary triggers, in both women and men. In Table 1, it is described the main group of trigger factors and its distribution according to gender.

Table 2. Number and percentage distribution of dietary trigger factors in migraine patients according to gender.

\begin{tabular}{|c|c|c|c|c|c|c|}
\hline \multirow[t]{2}{*}{ Dietary factor } & \multicolumn{2}{|c|}{ Total } & \multicolumn{2}{|c|}{ Female } & \multicolumn{2}{|c|}{ Male } \\
\hline & $\mathrm{n}$ & $\%$ & $\mathrm{n}$ & $\%$ & $\mathrm{n}$ & $\%$ \\
\hline Chocolate & 41 & 20.50 & 37 & 22.84 & 4 & 10.53 \\
\hline Sausage & 12 & 6.00 & 9 & 5.55 & 3 & 7.89 \\
\hline Salami & 9 & 4.50 & 7 & 4.32 & 2 & 5.26 \\
\hline Monosodium glutamate & 5 & 2.50 & 5 & 3.09 & 0 & 0 \\
\hline Cheese & 17 & 8.50 & 15 & 9.26 & 2 & 5.26 \\
\hline Milk & 5 & 2.50 & 5 & 3.09 & 0 & 0 \\
\hline Aspartame & 17 & 8.50 & 14 & 8.64 & 3 & 7.89 \\
\hline Alcohol & 68 & 34.00 & 53 & 32.72 & 15 & 39.47 \\
\hline Red wine* & 39 & 19.50 & 36 & 22.22 & 3 & 7.89 \\
\hline White wine & 21 & 10.50 & 18 & 11.11 & 3 & 7.89 \\
\hline Others & 40 & 20.00 & 31 & 19.13 & 9 & 23.68 \\
\hline Coffee & 29 & 14.50 & 21 & 12.96 & 8 & 21.05 \\
\hline Soft drink & 3 & 1.50 & 1 & 0.62 & 2 & 5.26 \\
\hline Citric fruits & 8 & 4.00 & 8 & 4.94 & 0 & 0 \\
\hline Icecream & 6 & 3.00 & 4 & 2.47 & 2 & 5.26 \\
\hline Nuts & 3 & 1.50 & 2 & 1.23 & 1 & 2.63 \\
\hline Minimun of 1 factor & 128 & 64 & 105 & 64.81 & 23 & 60.52 \\
\hline Minimun of 2 factors & 79 & 39.50 & 65 & 40.12 & 14 & 36.84 \\
\hline Minimun of 3 factors & 46 & 23.00 & 37 & 26.84 & 9 & 23.68 \\
\hline Minimun 4 factors & 28 & 14.00 & 24 & 14.81 & 4 & 10.53 \\
\hline Minimun 4 factors & 16 & 8.00 & 14 & 8.64 & 2 & 5.26 \\
\hline 5 Or more factors & 8 & 4.00 & 6 & 3.70 & 2 & 5.26 \\
\hline
\end{tabular}

All the elements have no significant distribution with the exception of red wine, that has the significance of $p<0.05$ 
Table 3. Number and percentage distribution of stress as trigger factors in migraine patients according to gender.

\begin{tabular}{|c|c|c|c|c|c|c|}
\hline \multirow[t]{2}{*}{ Stress } & \multicolumn{2}{|c|}{ Total } & \multicolumn{2}{|c|}{ Female } & \multicolumn{2}{|c|}{ Male } \\
\hline & $\mathrm{n}$ & $\%$ & $\mathrm{n}$ & $\%$ & $\mathrm{n}$ & $\%$ \\
\hline Stress at & 123 & 61.50 & 100 & 61.7 & 23 & 60.50 \\
\hline Work & 103 & 51.50 & 81.00 & 50.00 & 22 & 57.89 \\
\hline Home & 72 & 36.00 & 62.00 & 38.27 & 10 & 26.31 \\
\hline Family & 19 & 9.50 & 16.00 & 9.88 & 3 & 7.89 \\
\hline Crying & 9 & 4.50 & 7.00 & 4.32 & 2 & 5.26 \\
\hline Conflict & 5 & 2.50 & 3.00 & 1.85 & 2 & 5.26 \\
\hline Argument & 9 & 4.50 & 7.00 & 4.32 & 2 & 5.26 \\
\hline Aggressiveness & 1 & 0.50 & 0.00 & 0 & 1 & 2.63 \\
\hline Minimun of 1 factor & 128 & 64.00 & 104.00 & 64.10 & 24 & 63.10 \\
\hline Minimun of 2 factors & 70 & 35.00 & 58.00 & 35.80 & 12 & 31.50 \\
\hline 3 or more factors & 19 & 9.50 & 17.00 & 10.50 & 2 & 5.26 \\
\hline
\end{tabular}

Table 4. Number and percentage distribution of sleep as trigger factors in migraine patients according to gender.

\begin{tabular}{lcccccccc}
\hline Sleep & \multicolumn{2}{c}{ Total } & & \multicolumn{2}{c}{ Female } & & \multicolumn{2}{c}{ Male } \\
\cline { 2 - 3 } \cline { 7 - 9 } & $\mathrm{n}$ & $\%$ & & $\mathrm{n}$ & $\%$ & & $\mathrm{n}$ & $\%$ \\
\hline Oversleep & 88 & 44.00 & & 71 & 43.83 & & 17 & 44.74 \\
Lack of sleep & 123 & 61.50 & & 99 & 61.11 & & 24 & 63.16 \\
Changes in time of sleep & 65 & 32.50 & & 56 & 34.57 & & 9 & 5.55 \\
Weekends & 7 & 3.50 & & 7 & 4.32 & & 0 & 0.00 \\
Minimun of 1 factor & 151 & 75.50 & & 123 & 75.92 & & 28 & 73.68 \\
Minimun of 2 factors & 86 & 43.00 & & 71 & 43.83 & & 15 & 39.47 \\
3 or more factors & 44 & 22.00 & & 37 & 22.84 & & 7 & 18.42 \\
\hline
\end{tabular}

In Table 2, the dietary triggers are listed in detail. Fasting was the most frequent one, followed by alcohol, chocolate, red wine and coffee. Alcohol intake in general, chocolate, red wine and coffee were also significant. The result of chi-square test showed that women had significantly more migraines trigger by red wine than men. In Table 3, stress is described. Work is the main cause of stress in patients with migraine, being the first for the women and men. Moreover, other situations regarding daily routine as family and home, such as arguments between people were also seen as precipitating factors of migraine. Furthermore, sleep behaviour (oversleep or lack of sleep) seems to have an influence in the migraine occurrence (Table 4).

All the environmental factors are described in Table 5. The most frequent were sun/clarity and cigarette smoking. Regarding odors, pefume smell was the most frequent one, followed by gasoline and considering air conditioning as a factor, the most important was car air conditioning.

Exertional activities were also asked, being physical activity the most frequent one.The minority (15.5\%) presented at least one exertional trigger factor, $2.0 \%$ report- ed at least 2 factors and just 1.0\% presented 3 or more factors, being the average 0.23 factors. Although low in percentages, exertional triggers may be important due to its ominous origin in selected cases (Fig 1).

One specific part of the study was dedicated to hormonal related issues in women, menstruation, pregnancy, menopause, ovulation and hormonal responses as a precipitating factor in migraine. The element pregnancy was reported by one patient and menopause by none. Furthermore, ovulation and hormonal replacement were cited by three patients each. Therefore, the majority (54.32\%) presented at least one hormonal trigger factor, $19.14 \%$ reported at least 2 factors and just $0.62 \%$ presented 3 or more factors (Fig 2).

The five main trigger factors reported by the patients were fasting, followed by stress and lack of sleep (Fig 3). Then, other factors as smell and pre menstrual period were also cited.

\section{DISCUSSION}

Trigger factors are very important for migraine pa- 
Table 5. Number and percentage distribution of environmental as trigger factors in migraine patients according to gender.

\begin{tabular}{|c|c|c|c|c|c|c|}
\hline \multirow[t]{2}{*}{ Environmental } & \multicolumn{2}{|c|}{ Total } & \multicolumn{2}{|c|}{ Female } & \multicolumn{2}{|c|}{ Male } \\
\hline & $\mathrm{n}$ & $\%$ & $\mathrm{n}$ & $\%$ & $\mathrm{n}$ & $\%$ \\
\hline Allergy & 11 & 5.50 & 11 & 6.79 & 0 & 0 \\
\hline Pollution & 14 & 7 & 11 & 6.79 & 3 & 7.89 \\
\hline Wind & 5 & 2.50 & 4 & 2.47 & 1 & 2.63 \\
\hline Rain & 3 & 1.50 & 1 & 0.62 & 2 & 5.26 \\
\hline Height & 4 & 2 & 4 & 2.47 & 0 & 0 \\
\hline Sun / Clarity & 28 & 14 & 23 & 14.20 & 5 & 13.16 \\
\hline Cold weather & 18 & 9 & 15 & 9.26 & 3 & 7.89 \\
\hline Hot weather & 19 & 9.50 & 13 & 8.02 & 6 & 15.79 \\
\hline Changes in the weather & 7 & 3.50 & 5 & 3.09 & 2 & 5.26 \\
\hline Cigarette smoking & 22 & 11 & 19 & 11.73 & 3 & 7.89 \\
\hline Air conditioning of & 52 & 26 & 43 & 26.54 & 9 & 23.68 \\
\hline car & 23 & 11.50 & 20 & 12.34 & 3 & 7.89 \\
\hline home & 13 & 6.50 & 11 & 6.79 & 2 & 5.26 \\
\hline work & 16 & 8 & 12 & 7.41 & 4 & 10.53 \\
\hline Smell & 71 & 35.50 & 63 & 38.90 & 8 & 21.10 \\
\hline perfume & 60 & 30 & 53 & 32.72 & 7 & 18.42 \\
\hline food & 15 & 7.50 & 13 & 8.02 & 2 & 5.26 \\
\hline fat & 6 & 3.00 & 5 & 3.09 & 1 & 2.63 \\
\hline cleanness product & 21 & 10.50 & 18 & 11.11 & 3 & 7.89 \\
\hline gasoline & 22 & 11.00 & 20 & 12.34 & 2 & 5.26 \\
\hline Minimun of 1 factor & 116 & 58.00 & 100 & 61.73 & 16 & 42.10 \\
\hline Minimun of 2 factors & 76 & 38.00 & 65 & 40.12 & 11 & 28.95 \\
\hline Minimun of 3 factors & 44 & 22.00 & 38 & 23.45 & 6 & 15.79 \\
\hline Minimun of 4 factors & 25 & 12.50 & 22 & 13.58 & 3 & 7.89 \\
\hline Minimun of 5 factors & 16 & 8.00 & 14 & 8.64 & 2 & 5.26 \\
\hline 5 or more factors & 11 & 5.5 & 9 & 5.56 & 2 & 5.26 \\
\hline
\end{tabular}

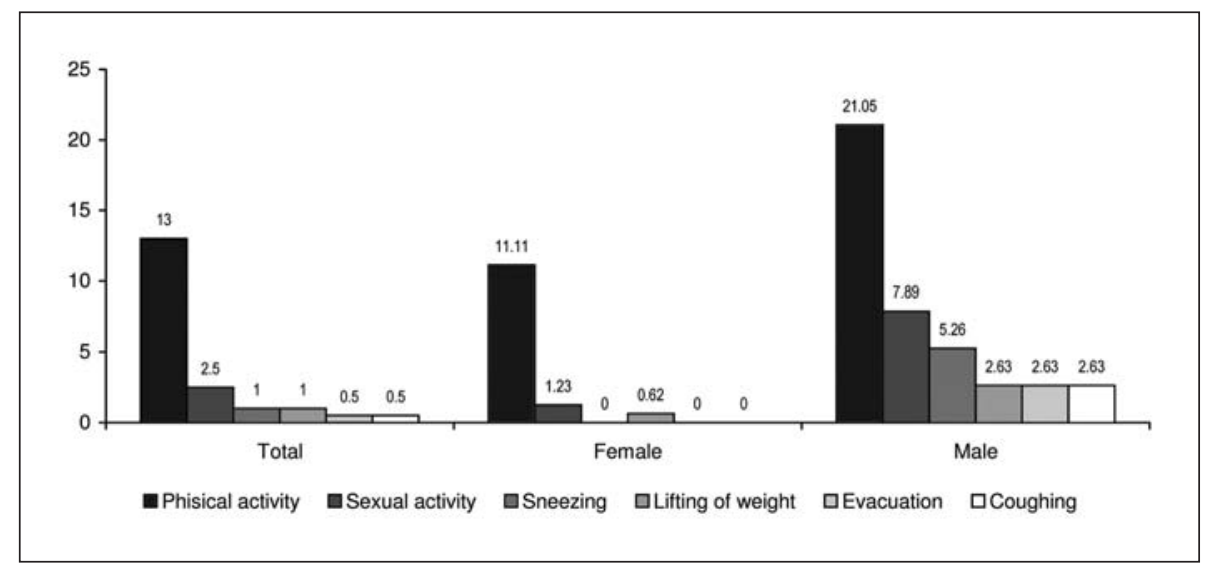

Fig 1. Number and percentage distribution of exertional activities as trigger factors in migraine patients according to gender. 


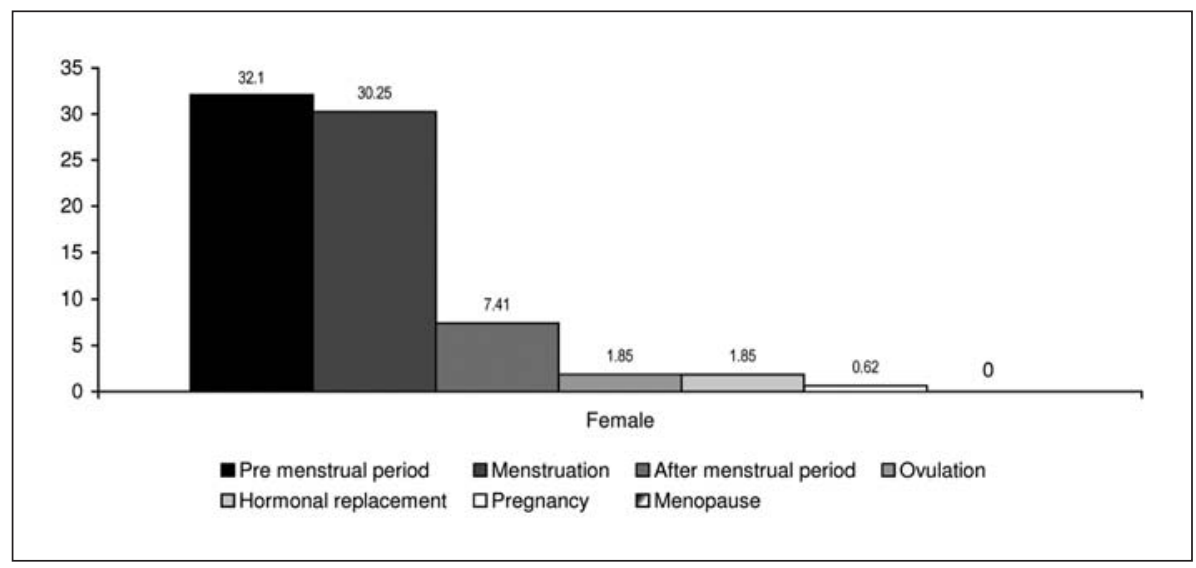

Fig 2. Number and percentage distribution of hormonal factors in migraine.

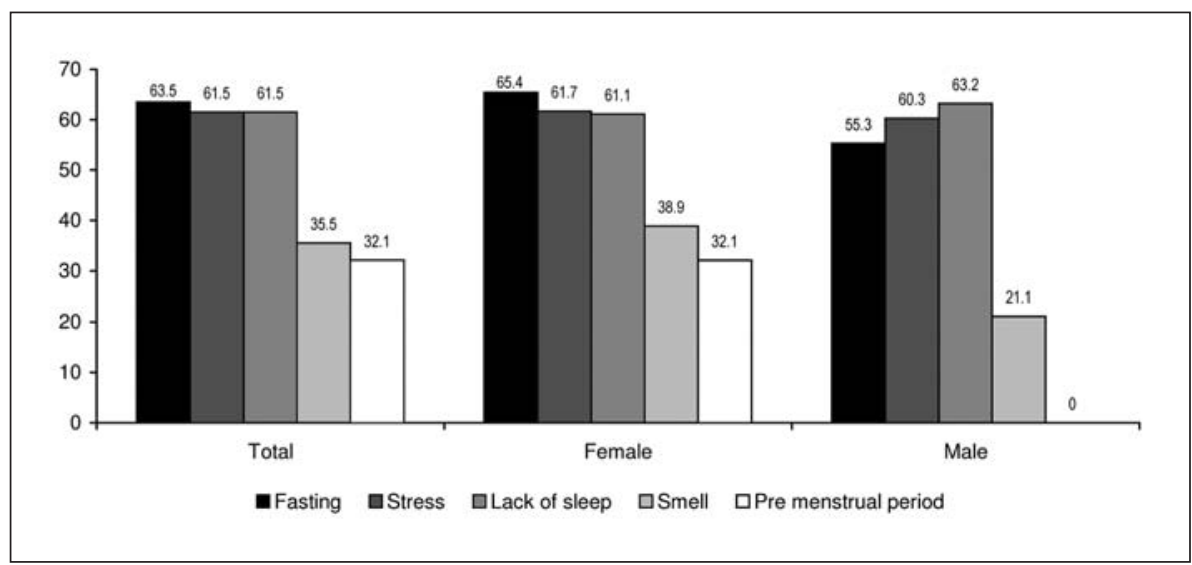

Fig 3. Number and percentage distribution of the more frequents trigger factors in migraine patients according to gender.

tients, we could observe that all patients had at least one trigger factor and around of $95.5 \%$ had at least 2 trigger factors. Therefore, studying its distribution and characteristics in a Brazilian population elucidates what clinicians will face in daily practice. Although relevant to migraine management trigger factors have never been studied in a large sample of Brazilian migraineurs. This study is to our knowledge the first of a kind to assess this issue in our population.

Analyzing as a group, our study indicated the most frequent precipitating factors reported by patients were dietary (84.5\%), sleep (75. $5 \%$ ), environmental $(68.5 \%)$, stress (65\%), hormonal factors (43.5\%) and exertional activities (15. 5\%). Each group researched was subdivided into several elements and the most cited trigger factors was fasting (63. 5\%), stress (61. 5\%), and lack of sleep (61. 5\%). According to Spierings et al. ${ }^{4}$, stress/ tension was the most frequent trigger factor (84\%), followed by fasting (82\%) and sleeplessness $(74 \%)$. In different studies ${ }^{6-8}$, stress was reported as the most significant factor $(72.4 \%$ by Scharff et al. ${ }^{8}$ and $62 \%$ by Robbins ${ }^{7}$ ). These results, in addition to the findings in our study, suggest that psychological management, dietary orientation and sleep hygiene recommendations should be important for migraine patients.

Fasting was the most cited aspect overall, followed by alcohol intake, chocolate and caffeine consumption, which is in accordance to the literature consulted ${ }^{4,6,7}$. Interestingly, wine was significantly more common as a trigger in women than men, showing that women are more sensitive to red wine than men. Many reasons may be related to this finding, such as different drinking habits in women compared to men, genetically and/or hormonal mediated susceptibility.

Hormonal and genetic factors may explain this finding. Dietary triggers may be overrepresented in this study because it was the first to be asked in the list of triggers, when we analyze the factors isolated, not grouped, we can see stress and sleep problems as emerging aspects, with similar percentages, and magnitude.

Hormonal factors are very important as triggers in women, mainly the pre menstrual period $(26 \%)$ and the 
menstrual period (24.5\%) itself, both reported other authors (Scharff et al. ${ }^{8}$ and Beckham et al. ${ }^{9}$ ).

Karli et al. ${ }^{3}$ reported similar percentages comparing to our study, fasting (78.3\%) was the most significant factor, followed by sleeplessness (65.2\%), stress/anxiety (78.3\%) and menstruation (56.5\%). For Chabriat et al. ${ }^{5}$ the main precipitating factors were fatigue and/or sleep, stress, food and/or drinks, menstruation, heat/cold/weather, agreeing with our study.

Physical activities appeared in 13\% of patients in our study. Although low in percentages, exertional triggers may be important due to its ominous origin in selected cases. Amery and Van den Bergh ${ }^{10}$ have suggested that headache triggers such as stress, alcohol, or the beginning of menses could make an individual more sensitive to other migraine triggers.

In conclusion, trigger factors are frequent in migraine patients, its detection must be detailed, so preventive treatment could be more efficient. Another conclusion was that women are more sensitive to red wine as a trigger factor than men. Avoiding migraine triggers factors can possibly decrease headache frequency and also potentially improve patients' quality of life.

\section{REFERENCES}

1. Krymchantowski AV, Moreira PF Filho. Atualização no tratamento profilático das enxaquecas. Arq Neuropsiquiatr 1999;57:513-519.

2. Peres MF, Sanchez del Rio M, Seabra ML, et al. Hypothalamic involvement in chronic migraine. J Neurol Neurosurg Psychiatry 2001;71:747-751.

3. Karli N, Zarifoglu M, Calisir N, Akgoz S. Comparison of pre-headache phases and trigger factors of migraine and episodic tension-type headache: do they share similar clinical pathophysiology? Cephalalgia 2005; 25:444-451.

4. Spierings ELH, Ranke AH, Honkoop PC. Precipitating and aggravating factors of migraine versus tension-type headache. Headache 2001; 41:554-558.

5. Olesen J. The International Classification of Headache Disorders, $2^{\text {nd }}$ edition. Cephalalgia 2004;24(Suppl 1):S9-S160.

6. Chabriat H, Danchot J, Michel P, Joire JE, Henry P. Precipitating factors of headache: a prospective study in a national control-matched survey in migraineurs and nonmigraineurs. Headache 1999;39:335-338.

7. Robbins L. Precipitating factors in migraine: a retrospective review of 494 patients. Headache 1994;34:214-216.

8. Scharff L, Turk DC, Marcus DA.Triggers of headache episodes and coping responses of headache: diagnostic groups pain evaluation and treatment institute, University of Pittsburg School of Medicine. Headache 1995;35:397-403.

9. Beckham JC, Krug LM, Penzien DB, et al. The relationship of ovarian steroids, headache activity and menstrual distress: a pilot study with female migraineurs. Headache 1992;32:292-297.

10. Amery WK, Vandenbergh V.What can precipitating factors teach us about the pathogenesis of migraine? Mechanism of migraine triggers. Headache 1987;27:146-150. 